\title{
TIMP-2 gene transfer by positively charged PEG-lated monosized polycationic carrier to smooth muscle cells
}

\author{
Nelisa Laçin • Güldem Utkan • Tülin Kutsal • \\ Bala Gür Dedeoğlu • Işık G. Yuluğ • Erhan Pişkin
}

Received: 17 December 2010/Accepted: 26 December 2011/Published online: 28 January 2012

(C) Springer Science+Business Media B.V. 2012

\begin{abstract}
Remodeling of the extracellular matrix resulting from increased secretion of metalloproteinase enzymes is implicated in restenosis following balloon angioplasty. Matrix metalloproteinases (MMPs) and the tissue inhibitors of metalloproteinases play an essential role in both normal and pathological extracellular matrix degradation. Tissue inhibitor of matrix metalloproteinase-2 is the most extensively studied tissue inhibitor of metalloproteinases in myocardial tissue in animal models and clinical examples of cardiac disease; therefore it is
\end{abstract}

N. Laçin $(\bowtie)$

Advanced Technology Education, Research and Application Center, Mersin University, 33343 Mersin, Turkey

e-mail: melisalacin@yahoo.com

G. Utkan

Enzyme and Fermentation Technology Laboratory, Genetic Engineering and Biotechnology Institute,

TUBITAK MAM, 41470 Gebze, Kocaeli, Turkey

T. Kutsal

Chemical Engineering Department and Bioengineering Division, Hacettepe University, 06800 Ankara, Turkey

B. G. Dedeoğlu · I. G. Yuluğ

Department of Molecular Biology and Genetics, Faculty of Science, Bilkent University, 06800 Bilkent, Ankara, Turkey

E. Pişkin

Chemical Engineering Department and Bioengineering Division and Center for Bioengineering-Biyomedtek, Hacettepe University, Ankara, Turkey selected for this study. Gene transfer of tissue inhibitor of matrix metalloproteinase-2 may have a therapeutic potential by inhibition of matrix metalloproteinase activity. We have used PEG-lated nanoparticles poly(St/PEG-EEM/DMAPM) which were synthesized previously in our laboratory. The nanoparticles, with an average size of $77.6 \pm 2.05 \mathrm{~nm}$ with a zeta potential of $+64.4 \pm 1.14 \mathrm{mV}$ and $201.9 \pm 1.83 \mathrm{~nm}$ with $+54.2 \pm$ $0.77 \mathrm{mV}$ were used in the transfection studies. Zeta Potential values and size of polyplex were appropriate for an effective transfection. TIMP-2 expression was detected by western blotting. Increased protein level in smooth muscle cells according to non-transfected smooth muscle cells confirms the successful delivery and expression of the tissue inhibitor of matrix metalloproteinase-2 gene with the non-viral vector transfection approach.

Keywords Gene therapy - Nanoparticles - SMC · TIMP · Nanomedicine

\section{Introduction}

Restenosis is the last stronghold to be conquered in cardiac revascularization therapy, which will be more increasingly performed as atherosclerosis becomes a global health problem in the twenty-first century (Libby 2002). Two distinct processes contribute to restenosis: the increased cellular mass in the intima (neointimal proliferation) and the negative remodeling of the artery. 
A new molecular approach will lead to the discovery of effective antirestenosis molecules that block both neointimal proliferation and negative remodeling. Vascular smooth muscle cells will be the most promising cell type to be targeted (Chen and Fujise 2005). Evidence suggests that vascular injury activates medial VSMCs, changing them from a quiescent to a proliferative phenotype, allowing them to migrate from the media into the intima. Intriguingly, neointimal hyperplasia was paradoxically blocked when a caspase inhibitor (Beohar et al. 2004) or an antiapoptotic gene (Tulis et al. 2003) was delivered immediately after balloon vascular injury. In normal physiological vascular remodeling, the activities of MMPs are tightly regulated at the transcription level, activation of their pro-form or zymogens, the interaction with specific ECM components, and the inhibition by endogenous inhibitors. Factors that promote vessel remodeling upregulate MMP activities and include chronic changes in hemodynamics, vessel injury, inflammatory cytokines, and reactive oxygen species (Raffetto and Khalil 2008). Control over MMP and/or the tissue inhibitors of metalloproteinases (TIMPs) activity in vivo occurs at different levels and involves factors such as regulation of gene expression, activation of zymogens and inhibition of active enzymes by specific inhibitors. Many MMPs and TIMPs are regulated at the level of transcription by a variety of growth factors, cytokines and chemokines (Yan and Boyd 2007). Perhaps more importantly, the interruption of MMPs activity by tissue inhibitor metalloproteinase infection has been shown to limit smooth muscle cells (SMCs) proliferation and migration through various models (George et al. 2000; Fernandez et al. 1998). The effects of local gene transfer of tissue inhibitor of metalloproteinase-2(TIMP-2) on vein graft remodeling were studied with Mouse. The findings demonstrate that local TIMP-2 (recombinant adenoviruses overexpressing human TIMP-2, RAdTIMP-2) gene transfer significantly reduces vein graft diameter, i.e., remodeling to an artery-like vessel via inhibition of matrixmetalloproteinase activity (Hu et al. 2001). In our previous studies, water-soluble polycationic temperature-responsive (smart) poly(nisopropylacrylamide)-polyethyleneimine block copolymers and monosizedpolycationicnanoparticules with different properties were synthesized and used successfully for the in vitro and invivo transfection of HeLa cells (Pişkin et al. 2004; Dinçer et al. 2002; Dinçer et al. 2005; Turk et al. 2004 and Guven et al. 2008). We have tested PEG- latedpoly[styrene/poly(ethyleneglycol)ethylethermethacrylate/ $N$-(3-(dimethylamino)propyl) methacrylamide [poly(St/PEG-EEM/DMAPM)] in two different sizes as a carrier molecule which were synthesized previously in our laboratory. PEG is the polymer of choice for protein modification because it possesses several favorable properties such as the lack of immunogenicity, antigenicity, and toxicity, and a high solubility in water and in many organic solvents. PEG is also approved by the FDA for human use. Common reasons for the PEGylation of a drug are to reduce its excretion by the kidneys, to avoid or reduce its degradation by proteolytic enzymes and/or hydrolytic media, to enhance its water solubility (for highly hydrophobic molecules), to reduce its reticuloendothelial (RES) clearance and to reduce its immunogenicity and antigenicity (mainly for peptides and proteins). PEG is very useful because of its ease of preparation, relatively low cost, controllable molecular weight and the ability to link it to lipids or protein (including antibody) by a variety of methods ( $\mathrm{Lv}$ et al. 2006; Kopecek et al. 2000; Harris and Chess 2003). Examination of in vitro particle internalization by transmission electron microscopy shows unmodified polyplexes entering cells as large aggregates, while PEGylated particles remain small and discrete, both outside and within cells. Unmodified and PEGylated particles enter cells through the endocytic pathway and accumulate in a perinuclear region. Immunolabeling reveals unpackaged exogenous DNA in the cytoplasm and nuclei. It appears that all particle types traffic towards the nucleus within vesicles and undergo degradation in vesicles and/or cytoplasm, and eventually some exogenous DNA enters the nucleus, where it is transcribed. In comparing polyplexes and their PEGylated variants, significant differences in particle morphology, cellular uptake, and resultant expression suggest that in vitro studies should be conducted with particles prepared for physiological conditions if the results are to be relevant to in vivo performance (Mishra et al. 2004).

\section{Materials and methods}

\section{Materials}

Styrene (St; Sigma, USA) was used as the main monomer, and was distilled before use. The cationic comonomer, $N$-3-(dimethylamino)propyl)methacrylamide 
(DMAPM; Sigma, USA) and polymerizable stabilizer, poly(ethylene glycol) ethyl ether methacrylate (PEGEEM; MW360; Aldrich, USA) were used as purchased. 2,2-azobis(2-methylpropionamidine)dihydrochloride (APDH; Aldrich, USA) was used as the cationic initiator. The dispersion medium was distilled water. DMEM without glutamine, supplemented fetal calf serum (FCS) and trypsin EDTA were purchased from Biological Industries (Israel). The plasmid used for inhibition of MMP2 was pBLAST TIMP-2 (Invivogen, USA). Bactotryptone and Bacto yeast extract were purchased from Difco, USA.

Nanoparticle production

Polymerizations were conducted in an oil-in-water system. In a typical procedure, the comonomers, St (1.25 mL), DMAPM (0.1 mL), PEG-EEM (0.1 mL) and the initiator, APDH $(0.03 \mathrm{~g})$, were added to distilled water(i.e. the dispersion medium) $(120 \mathrm{~mL})$, in a Pyrex glass reactor. Polymerizations were carried out in a constant temperature-shaking bath at 65 and $60^{\circ} \mathrm{C}$, under a nitrogen atmosphere for a polymerization period of $24 \mathrm{~h}$. These conditions were determined in the preliminary experiments. The reaction was carried out in acidic medium ( $\mathrm{pH}$ 2.5-3.0). The latex particles were cleaned by washing with methanol and water several times to remove the unreacted monomers. Cationic charge carrying stable nanoparticles were synthesized in a different particle size. FTIR (FTIR 8000, Shimadzu, Japan) and ${ }^{1}$ H-NMR (Bruker Avance DPX-400, Germany-Sweden) spectroscopies were used to characterize the chemical structure of the nanoparticles. The average particle size and the size distribution and the surface charge were determined by a Zeta Sizer (Malvern 3000 HSA, UK). AFM was employed for the imaging of the nanoparticles (Guven et al. 2004).

Preparation of the plasmid-nanoparticle complex and characterization

Plasmid DNA encoding TIMP-2 (pBLAST TIMP-2) was amplified to sufficient quantities in $E$. coli DH5 $\alpha$ competent bacteria and purified with a Qiagen Midiprep kit (Qiagen, USA). DNA quantification was performed by UV spectrophotometry at $260 \mathrm{~nm}$ and DNA was run on $1.2 \%$ agarose gel for quality control.
Polymer suspensions were prepared by different amounts of either poly(St/PEG-EEM/DMAPM) $77.6 \mathrm{~nm}$ or poly(St/PEG-EEM/DMAPM) $201.9 \mathrm{~nm}$ in $0.15 \mathrm{M} \mathrm{NaCl}$. Different amounts of pBLAST TIMP-2 were dispersed in $500 \mu \mathrm{l} 0.15 \mathrm{M} \mathrm{NaCl}$. These solutions were then mixed and incubated for $15 \mathrm{~min}$ in order to complete complex formation. Sizes and zeta potentials of pDNA and copolymer-pDNA complexes were measured at $25^{\circ} \mathrm{C}$ using a Zeta Sizer HSA3000 (Malvern Instruments, France).

\section{Cytotoxicity}

For cytotoxicity experiments, primary smooth muscle cells $\left(15 \times 10^{3}\right.$ cells/well $)$ were placed in DMEM without glutamine, using 96-well plates. Cell viability studies in the presence of test substances were performed via the MTT test. Thereafter, the medium was replaced with DMEM containing no FCS antibiotics, poly(St/PEG-EEM/DMAPM) nanoparticles with two different diameters 77.6 and $201.9 \mathrm{~nm}$ were added into the medium (different amounts of nanoparticles in the range $25-60 \mu \mathrm{g}$ polymer/well). After $4 \mathrm{~h}$ of incubation, solutions were removed and each well was treated with $13 \mu \mathrm{l}$ methylthiazol tetrazolium (5 mg MTT/mL in medium without phenol red) and incubated for a further $4 \mathrm{~h}$ at $37^{\circ} \mathrm{C}$ in a humidified atmosphere of $5 \% \mathrm{CO}_{2}$. Then, MTT solution was replaced by $100 \mu \mathrm{l} /$ well of isopropanol in order to dissolve the formazane crystals. The absorbances of the solutions were read at $570 \mathrm{~nm}$ in a microplate reader (Biotek Instruments, USA). Additionally, cell viability was calculated from this data as below:

Cell viability (\%)

$=($ viable cell number $/$ total cell number $) \times 100$

The viability of the cells with respect to the control (containing no polymeric nanoparticles) was also determined for normalization of the results (Laçin et al. 2011; Guven et al. 2008).

In vitro transfection

For gene expression studies, primary smooth muscle cells (SMCs) and DMEM without glutamine, supplemented with $10 \%$ FCS and $10 \mu \mathrm{l} / \mathrm{mL}$ penicillinstreptomycin solution, was used as the growth medium (Türk et al. 2007). $25 \mathrm{~cm}^{2}$ cell culture plates were used 
with $1 \times 10^{6}$ cells for the transfection studies. These plates were incubated at $37^{\circ} \mathrm{C}$ in $5 \% \mathrm{CO}_{2}$ for $24 \mathrm{~h}$. In response to injury, the ECM undergoes remodeling that involves synthesis, incorporation, and degradation of matrix proteins, with the net outcome determined by the balance of these processes. Therefore, SMC injury was created by gentle pressure with a 3-mmwide soft plastic tube to the bottom of the culture dish for $5 \mathrm{~s}$ (Jourdan-LeSaux et al. 2010). Prior to injury, the cells were provided with fresh serum and antibiotic-free medium and transfection solution (complexes described above; the polymer amount used for every culture plate was $3 \mathrm{mg}$ ) were added in each culture plate. The wells were incubated $37^{\circ} \mathrm{C}$ in $5 \%$ $\mathrm{CO}_{2}$ for $4 \mathrm{~h}$. Afterward the medium in each well was replaced with fresh DMEM with FCS and antibiotics. Western blotting was performed with cell extract isolated from SMCs.

\section{Western blotting}

The cell extract was a mixture of injured transfected cells and was collected at 24, 48, and $64 \mathrm{~h}$. pBLAST TIMP-2 transfected SMCs were collected after washing with PBS solution. SMCs were situated in eppendorf in pellet form. The PBS solution on the pellet was entirely removed and 30-40 $\mu$ lysis buffer was added on the pellet (up to 2.5 times the pellet). Pellets were incubated (vortex every $5 \mathrm{~min}$ ) for $30 \mathrm{~min}$ at $+4^{\circ} \mathrm{C}$. They were then centrifuged at $13.000 \mathrm{~g}$ for $30 \mathrm{~min}$ and the supernatant containing proteins was stored at $-80^{\circ} \mathrm{C}$. The amount of total protein obtained from the cell extract was determined by the Bradford assay. BSA stock solution was prepared at a concentration of $10 \mathrm{mg} / \mathrm{mL}$ and diluted to $0.5,1,2,4,8,10,12,14 \mu \mathrm{g} / \mathrm{mL}$ for the generation of standart curve. The concentrations of the proteins were calculated according to the reference absorbance values obtained from standart curve. $50 \mu \mathrm{g}$ of each protein sample was loaded on the SDS-PAGE gel.

Protein separation was performed on a $12 \%$ polyacrylamide gel in SDS running buffer (25 mM Tris$\mathrm{HCl}$ [pH 8.3], $192 \mathrm{mM}$ glycine, 0.1\% SDS). After electrophoresis, proteins were transferred to $0.45-\mu \mathrm{m}$ nitrocellulose membrane in a buffer containing $25 \mathrm{mM}$ Tris- $\mathrm{HCl}$ [pH 8.0] $192 \mathrm{mM}$ glycine, and $20 \%$ methanol at $4^{\circ} \mathrm{C}$. Nitrocellulose membranes were washed once in TBST (100 mM Tris- $\mathrm{HCl}$ [pH 8.0]
$150 \mathrm{mM} \mathrm{NaCl}$, and $0.2 \%$ Tween-20) and blocked for 30 min with TBST containing 3\% non-fat dry milk. Primary antibody to TIMP-2 (1:400, IM32L Santa Cruz biotechnology, US) was added to the blocking solution and allowed to incubate overnight at $4^{\circ} \mathrm{C}$. After four washes, $15 \mathrm{~min}$ each in TBST, and reblocking with $3 \%$ non-fat dry milk for $30 \mathrm{~min}$, secondary antibody rabbit anti-mouse HRP conjugated antibody (1:1000, A-9044; Sigma) was added and allowed to incubate for $1 \mathrm{~h}$ at room temperature. Blots were developed with the enhanced chemiluminescence detection system (Pierce Biotechnology, Rockford, IL, USA).

\section{Results and discussion}

Structural characterization of the polymers

Cationic nanoparticles were prepared by the emulsifierfree emulsion polymerization technique. Stable latexes were obtained and they kept their stability more than a year storage. Structural analysis of nanoparticles was realized by using FTIR and ${ }^{1}$ HNMR as shown in Fig. 1 (Guven et al. 2004). The following characteristic peaks were observed in the FTIR spectra of the nanoparticles synthesized (KBr, pellet), $\mathrm{cm}^{-1}: 3,300$ (w) secondary amide (NH stretching), 3,100-3,000 (m) aromatic $\mathrm{CH}$, 1,950 overtone bands of $\mathrm{C}=\mathrm{O}, 1,875$ and $1,800 \mathrm{C}=\mathrm{O}$, 1740 (s) $\mathrm{C}=\mathrm{O}$ stretching; 1640 (s) $\mathrm{N}-\mathrm{H}$ in-plane bending; 1600 aromatic benzene ring $(\mathrm{C}=\mathrm{C}$ stretch), 1,530 (s) $\mathrm{N}-\mathrm{H}$ stretching,, 1490 secondary amides $(\mathrm{NH}$ deformation, amide II band), 1,450 $\mathrm{CH}_{2}$ scissor vibration, 1,380 and 1,360 doublet twist bands for $\mathrm{CH}_{3}$ deformation, 1,335 (w) $\mathrm{CH}_{2}$ bending, 1,235 (w) transamide III band, 1,175 CN stretching in DMAPM unit, 1160, 1125 and 1075 (s) C-O-C stretch bands, 1,025 $\mathrm{CH}$ in-plane bending, 975-840 (m-w) $\mathrm{C}-\mathrm{C}$ stretching of main chain, 760 (s) $\mathrm{CH}$ out-of-plane deformation of monosubstituted benzene, 700 (s) $\mathrm{CH}$ rocking, 625 (w) out-of-plane $\mathrm{CH}$ deformation, 540 (s) $\mathrm{C}=\mathrm{O}$ out-of-plane bends.

A representative ${ }^{1} \mathrm{HNMR}$ spectra (in $\mathrm{CHCl}_{3}$-d1 at $27^{\circ} \mathrm{C}$ ) of nanoparticles, ppm, has characteristic peaks at: (1) $1 \mathrm{H}, \mathrm{CH}$ (backbone) $2.40-2.39$, (2) $2 \mathrm{H}, \mathrm{CH}_{2}$ (backbone) 1.72, (3-7) 5H, CH (benzene ring) (broad peaks) 6.97-7.02 for St unit; (8) $2 \mathrm{H}, \mathrm{CH}_{2}$ (backbone) 2.08-2.05, (9) $3 \mathrm{H}, \mathrm{CH}_{3} 1.19,(10-11) 2 \mathrm{H}, \mathrm{CH}_{2}$ 3.76-3.28, (12) $2 \mathrm{H}, \mathrm{CH}_{2} 3.43$, (13) $3 \mathrm{H}, \mathrm{CH}_{3}$ 

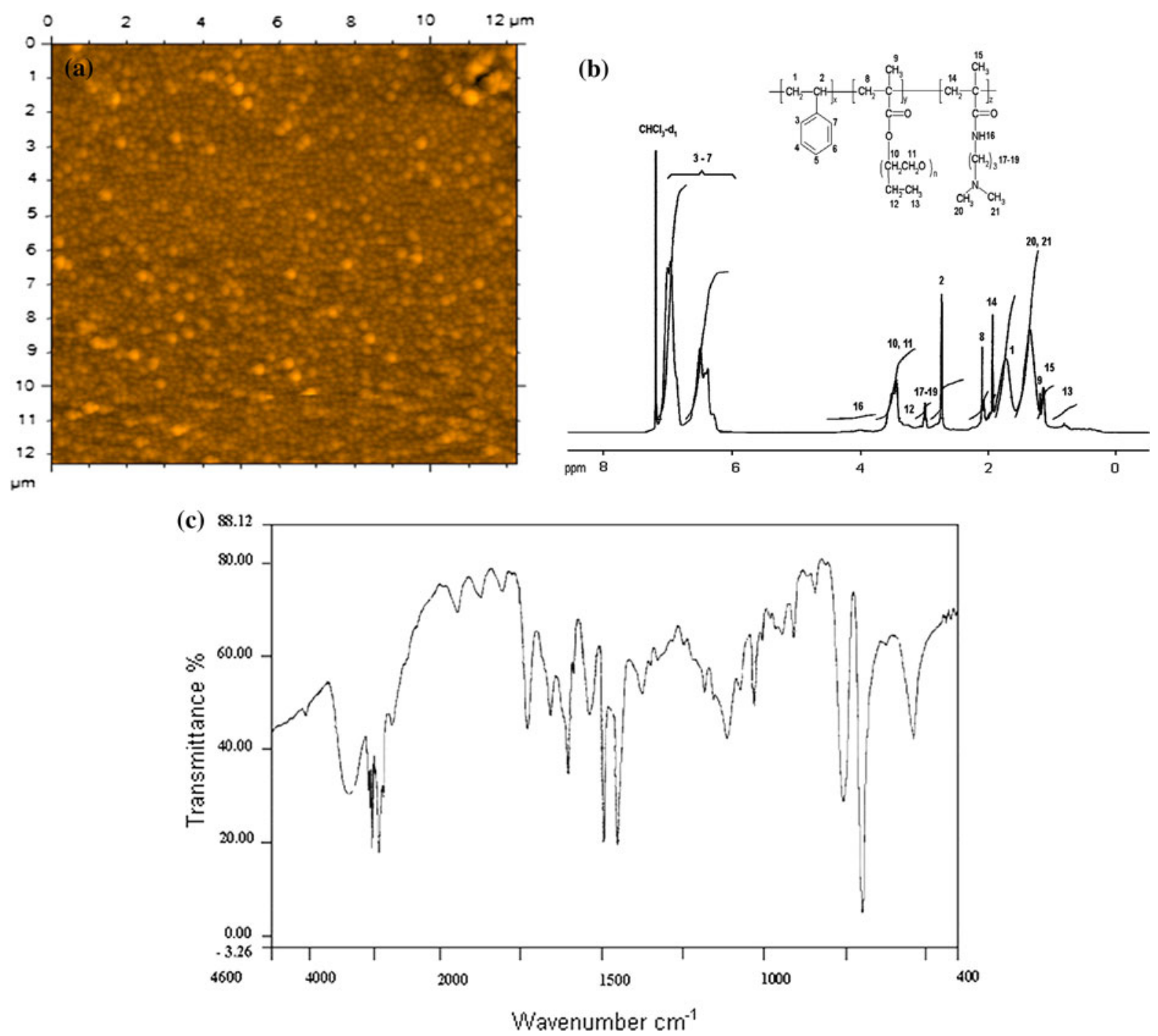

Fig. 1 a AFM image, b ${ }^{1}$ H-NMR spectra, $\mathbf{c}$ chemical formula and FTIR spectra of poly(St/PEG-EEM/DMAPM)

0.85-0.74 for PEG-EEM unit; (14) $2 \mathrm{H}, \mathrm{CH}_{2}$ (backbone) $1.98,(15) 3 \mathrm{H}, \mathrm{CH}_{3} 1.14,(16) 1 \mathrm{H}, \mathrm{NH}$ (broad peak) 4.194.19-3.90, (17- 19) $2 \mathrm{H}, \mathrm{CH}_{2}$ (broad peak) 3.17-3.02, (20-21) 3H, $\mathrm{CH}_{3} 1.35$ for DMAPM unit (Guven et al. 2004).
Zeta potentials and particle sizes

Zeta potentials and particle sizes of nanoparticles tested for polyplex preparation are given in Table 1 . The size and potential of free plasmid were found to be

Table 1 Zeta Sizer measurements of monosized PEGylated nanoparticles

\begin{tabular}{lcrr}
\hline Material & \multicolumn{1}{c}{ Size $(\mathrm{nm})$} & Polydispersity index & Zeta potential $(\mathrm{mV})$ \\
\hline PEG-EEM 78 & $77.6 \pm 2.05$ & $0.089 \pm 0.04$ & $+64.4 \pm 1.14(\mathrm{pH} 2.94)$ \\
PEG-EEM 200 & $201.9 \pm 1.83$ & $0.14 \pm 0.01$ & $+54.2 \pm 0.77(\mathrm{pH} \mathrm{3.36)}$ \\
\hline
\end{tabular}

${ }^{a}$ PEG-EEM 78 represents poly(St/PEG-EEM/DMAPM) $78 \mathrm{~nm}$ sized

b PEG-EEM 200 represents poly(St/PEG-EEM/DMAPM) $200 \mathrm{~nm}$ sized 
Table 2 Zeta Sizer Measurements of pDNA and poly(St/PEGEEM/DMAPM)/pBLAST TIMP-2 conjugates

\begin{tabular}{|c|c|c|c|c|}
\hline Material $(\mu \mathrm{g})$ & $\begin{array}{l}\text { Polymer } \\
\text { conc. } \\
(\mu \mathrm{g})\end{array}$ & $\begin{array}{l}\text { pDNA } \\
\text { conc. } \\
(\mu \mathrm{g})\end{array}$ & $\begin{array}{l}\text { Complex } \\
\text { diameter } \\
(\mathrm{nm})\end{array}$ & $\begin{array}{l}\text { Zeta } \\
\text { potential } \\
(\mathrm{mV})\end{array}$ \\
\hline pBLAST TIMP-2 & - & 20 & 475 & -37.5 \\
\hline $\begin{array}{r}\text { PEG-EEM } 78 \\
(\text { polyplex I) }\end{array}$ & 500 & 10 & 381 & -2.8 \\
\hline $\begin{array}{r}\text { PEG-EEM } 78 \\
\text { (polyplex II) }\end{array}$ & 625 & 5 & 1226 & +33.7 \\
\hline $\begin{array}{r}\text { PEG-EEM } 200 \\
\text { (polyplex III) }\end{array}$ & 500 & 5 & Agg. & -32.4 \\
\hline $\begin{array}{r}\text { PEG-EEM } 200 \\
\text { (polyplex IV) }\end{array}$ & 750 & 2 & Agg. & +1.6 \\
\hline
\end{tabular}

around $475 \mathrm{~nm},-32.7 \mathrm{mV}$. Nanoparticles with an average size of $77.6 \mathrm{~nm}$ with a zeta potential of $64.4 \mathrm{mV}$ and an average size of 201.9 with a zeta potential of $54.2 \mathrm{mV}$ were incubated with pBLAST TIMP-2 plasmid. The zeta potentials and particle size of nanoparticle/DNA complexes are shown in Table 2. Poly(St/PEG-EEM/DMAPM) nanoparticles have a permanent charge on their surfaces and they are in the nanometer size range. Both of these properties are advantages for easy entrance into the cells. By comparing the data, we can say that the zeta potential of plasmid DNA goes to positive values after complex formation. The procedure brings the negatively charged plasmid molecules to positive values that can interact with the negatively charged cell wall and enter the cells easily. We suppose that nanoparticles fit the spherical forms on the supercoiled plasmid DNA, interact with it, and help it to keep these configurations after internalization by the target cells.

After complex formation, smaller particles kept their stability, while larger particles formed agglomerations and precipitated. Smaller particles were therefore employed for transfection experiments for further study and the larger particles were kept aside.

In vitro cytotoxicity

The cytotoxicity of the vectors used in gene therapy is an important consideration. Following similar studies reported in the related literature, we investigated the in vitro cytotoxicity of the nanoparticles, using the MTT test, (Pişkin 2005). We observed cytotoxicity of poly(St/PEG-EEM/DMAPM) nanoparticles. Percentage of cell viability was 96 and $85 \%$ with the 77.6 and
Table 3 Cytotoxicity of nanoparticles determined by MTTassay

\begin{tabular}{llll}
\hline $\begin{array}{l}\text { Amount of nanoparticle into } \\
\text { medium }(\mu \mathrm{g} / \text { well })\end{array}$ & 20 & 45 & 60 \\
$\begin{array}{l}\text { Cell loss }(\%) \text { with poly } \\
\quad(\mathrm{St} / \mathrm{PEG}-\mathrm{EEM} / \mathrm{DMAPM})(78 \mathrm{~nm})\end{array}$ & 2 & 4 & 11 \\
$\begin{array}{l}\text { Cell loss }(\%) \text { with poly } \\
\quad(\mathrm{St} / \mathrm{PEG}-\mathrm{EEM} / \mathrm{DMAPM})(200 \mathrm{~nm})\end{array}$ & 7 & 15 & 20 \\
\hline
\end{tabular}

$201.9 \mathrm{~nm}$-sized nanoparticles, respectively, when the amount of nanoparticles corresponded to the concentration used in the transfection experiments and to the time used in the transfection period. The related results are summarized in Table 3. Cytotoxicity is mainly effected by the cationic charge density of the vector used. Moreover, chemical structure of the vector and cationic density effects toxicity (Lv et al. 2006). High cationic charge densities are required in order to form a complex with DNA, which allows a favorable cell uptake; on the contrary, complex dissociation is important for transcription by RNA polymerase. However, several groups have investigated that the cationic charge densities effect cell viability in a negative sense (Jeong et al. 2001; Fischer et al. 1999). The following results were drawn from study: the increase in the amount of polymer added in each well caused more toxicity (more dead cells) as expected but any distinct toxicity the polymer concentration that we have used for transfection to SMCs was not observed.

TIMP-2 protein levels in transfected SMCs

For effective polyplex-mediated gene delivery, the cationic polymer carrier has to fulfill a series of drug delivery functions during the extracellular and intracellular transport of the DNA vector. The polymer has to compact DNA into particles of virus-like dimensions that can migrate through the blood circulation into the target tissue, protect the DNA from degradation and against undesired interactions with the biological environment, and facilitate target cell binding and internalization (Mislick and Baldeschwieler 1996; Goncalves et al. 2002; Goncalves et al. 2004; Kopatz et al. 2004; Ruponen et al. 2004).

In our previous studies, poly(St/PEG-EEM/ DMAPM) nanoparticles were tested to see if they could be used as carrier molecules. Firstly, nanosphere/GFP-N2 complexes were prepared and zeta potential measurements were determined. The size 
and potential of free plasmid were found to be around $740 \mathrm{~nm}$ and $-21 \mathrm{mV}$. Conjugates with 78 and $200 \mathrm{~nm}$-sized poly(St/PEG-EEM/DMAPM) nanoparticles effectively carried GFP-N2 plasmid to SMCs in vitro (68 and 64\%, respectively) (Laçin et al. 2011). It was our hypothesis in this study that the plasmid encoding TIMP-2 transfer to SMCs could reduce SMC migration as increased levels of TIMP-2 immediately after injury inhibit matrix breakdown. It hasbeen shown that perivascular adenoviral gene delivery of TIMP-2 to the adventitial surface of mouse vena cava grafted onto mouse common carotid arteries inhibits MMP activity and significantly reduces graft neointimal hyperplasia at 2 to 4 weeks after grafting (Siow and Churchman 2007). We tested 78 and $200 \mathrm{~nm}$ sized poly(St/PEG-EEM/DMAPM) nanoparticles of TIMP-2 encoding plasmid transferring capacity to SMCs. Although polyplex I has an ideal particle size, the zeta potential of particle is not suitable to be used as a vector. A positive charge around $33 \mathrm{mV}$ and a complex size of $1,200 \mathrm{~nm}$ were determined with polyplex II, which seems proper for SMC transfection. However, the $200 \mathrm{~nm}$-sized particles aggregated after incubation with pBLAST TIMP-2, and the excess positive charge of polyplex III and IV were also very low. Even though the nanoparticle used in both studies (GFP-N2 and pBLAST TIMP-2) is the same, the final complex zeta potential and size has changed. This is due to the difference between the two plasmid DNAs carried. They have dissimilar structure, zeta values and sizes. We are therefore unable to say that TIMP-2 gene is expressed at the same percentage as GFP-N2. However, increased TIMP-2 protein levels in transfected cells compared to untransfected cells were detected. A clearly detectable $24 \mathrm{kD}$ band was noted in transfected cells collected $64 \mathrm{~h}$ later. The protein level is significantly increased in TIMP-2 transfected cells compared to non-transfected SMCs as seen in Fig. 2 encouraging further work on the inhibition of MMP activity with the poly(St/PEG-EEM/DMAPM) nanoparticle.

Two major classes of non-viral vectors that have shown relatively high efficiency are liposomal formulations and cationic polymers (polycations). Recent studies have shown that polycations are potentially superior to liposomal formulations in many respects (Thomas and Klibanov 2003). Although non-viral gene delivery systems have shown significant transfection efficiency in vitro, their applications have been

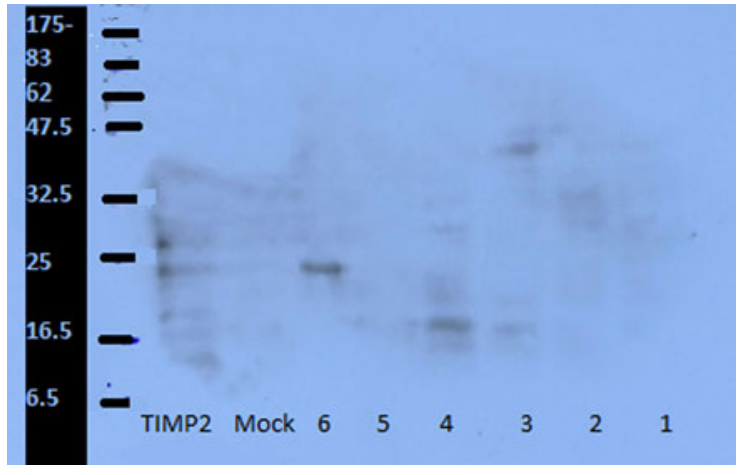

Fig. 2 Well \# 6, 5, and 4 represent SMCs transfected and collected in 64, 48, and $24 \mathrm{~h}$, respectively. Wells \# 3, 2, 1 represent SMCs controls (non-transfected cells) collected in 64, 48, and $24 \mathrm{~h}$, and Mock is the negative control

hampered by limited trafficking to the target site in vivo, substantial decreased transfection efficiency caused by non-specific interactions with serum components (Boussif et al. 1995) and large particle size. The main limitation of the approach is that the polycation/DNA complex may be too large to pass through blood vessel endothelium and reach target tissues via the vascular route. Most liposome/DNA or polycation/DNA complexes have diameters of $\sim 100$ to $500 \mathrm{~nm}$. The endothelial barrier would normally prevent particles of this size from crossing, except in organs such as the spleen and liver where the endothelium is discontinuous (Liang et al. 2004). Polyplex I with a 381-nm diameter size seems ideal for gene therapy but the low excess positive charge prevents it from penetrating the cell wall. Polyplex III and IV are not taken into account because of their agglomerating composition. Polyplex II has a sufficient excess positive charge (around $33 \mathrm{mV}$ ), besides a complex size of 1,200 nm. Polyplex II must be taken into account as a site-specific gene delivery system because of its large size.

\section{Conclusion}

Infusing drugs in solution at the site of injured artery is not successful in inhibiting restenosis because of the rapid wash-out. Gene therapy approach has been used to express therapeutic gene products. Viral vectors or lipid based vectors were used until now to transfect the TIMP encoding gene to SMCs. In this study, we focused on the prevention of restenosis by increased 
TIMP-2 protein levels in SMCs immediately after injury. For efficient pBLAST TIMP-2 transfer, we used effective non-viral vector systems which were synthesized in our lab. This PEG-lated monosized, non-toxic and highly positively charged nanoparticle poly(St/PEG-EEM/DMAPM) is an innovation. High surface charge carrying fine latex particles were successfully used in SMCs transfection studies. Could the future of restenosis treatment be in gene therapy by encoding the SMC anti-proliferative gene carried with poly(St/PEG-EEM/DMAPM) nanoparticle?

Acknowledgments This study was supported by the Turkish Scientific and Technological Council (Turkish Scientific and Technological Research Council, TÜBITAK; Project No. 104S334). Erhan Pişkin was also supported by the Turkish Academy of Sciences (TÜBA) as a full member.

\section{References}

Beohar N, Flaherty JD, Davidson CJ, Maynard RC, Robbins JD, Shah AP, Choi JW, MacDonald LA, Jorgensen JP, Pinto JV, Chandra S, Klaus HM, Wang NC, Harris KR, Decker R, Bonow RO (2004) Antirestenotic effects of a locally delivered caspase inhibitor in a balloon injury model. Circulation 109:108-113. doi:10.1161/01.CIR.0000105724.30980

Boussif O, Lezoualc'h F, Zanta MA, Mergn MD, Scherman D, Demeneix B, Behr JP (1995) A versatile vector for gene and oligonucleotide transfer into cells in culture and in vivo: polyethylenimine. Proc Natl Acad Sci USA 92:7297-7301

Chen X, Fujise K (2005) Restenosis: emerging molecular targets going beyond drug-eluting stents. Drug Discov Today 2:1-9. doi:10.1016/j.ddmec.2005.05.025

Dinçer S, Tuncel A, Pişkin E (2002) A potential gene delivery vector: nisopropylacrylamide-ethyleneimine block copolymers. Macromol Chem Phys 203:1460-1465. doi:10.1002/ 1521-3935(200207)203:10/1

Dinçer S, Türk M, Pişkin E (2005) Intelligent polymers as nonviral vectors. Gene Ther 12:139-145. doi:10.1038/sj.gt. 3302628

Fernandez HA, Kallenbach K, Seghezzi G, Mehrara B, Apazidis A, Baumann F, Grossi EA, Colvin S, Mignatti P, Galloway AC (1998) Modulation of matrix metalloproteinase activity in human saphenous vein grafts using adenovirus mediated gene transfer. Surgery 124:129-136. doi: 10.1016/S0039-6060(98)70112-6

Fischer D, Bieber T, Li Y, Elsasser HP, Kissel T (1999) A novel non-viral vector for DNA delivery based on low molecular weight, branched polyethleneimine: effect of molecular weight on transfection efficiency and cytotoxicity. Pharm Res 16:1273-1279. doi:10.1023/A:1014861900478

George SJ, Lloyd CT, Angelini GD, Newby AC, Baker AH (2000) Inhibition of late vein graft neointima formation in human and porcine models by adenovirus-mediated overexpression of tissue inhibitor of metalloproteinase-3. Circulation 101:296-304. doi:10.1161/01.CIR.101.3.296
Goncalves C, Pichon C, Guerin B, Midoux P (2002) Intracellular processing and stability of DNA complexed with histidylated polylysine conjugates. J Gene Med 4:271-281. doi:10.1002/jgm.27

Goncalves C, Mennesson E, Fuchs R, Gorvel JP, Midoux P, Pichon C (2004) Macropinocytosis of polyplexes and recycling of plasmid via the clathrin-dependent pathway impair the transfection efficiency of human hepatocarcinoma cells. Mol Ther 10:373-385. doi:10.1016/j.ymthe.2004.05.023

Guven G, Tuncel A, Piskin E (2004) Monosized cationic nanoparticles by emulsifier free emulsion polymerization and their characterization. Colloid Polym Sci 282:708-715

Guven G, Laçin N, Pişkin E (2008) Monosize polycationic nanoparticles as non-viral vectors for gene transfer to HeLa cells. J Tissue Eng Regen Med 2:155-163. doi:10.1002/term

Harris JM, Chess RB (2003) Effect of pegylation on pharmaceuticals. Nat Rev Drug Discov 2:214-221

Hu Y, Baker AH, Zou Y, Newby AC, Xu Q (2001) Local gene transfer of tissue inhibitor of metalloproteinase-2 influences vein graft remodeling in a mouse model. Arterioscler Thromb Vasc Biol 21:1275-1280. doi:10.1161/hq0801.093658

Jeong JH, Song SH, Lim DW, Lee H, Park TG (2001) DNA transfection using linear poly(ethylenimine) prepared by controlled acid hydrolysis of poly(2-ethyl-2-oxazoline). J Control Release 73:391-399. doi:10.1016/S01683659(01)00310-8

Jourdan-LeSaux C, Zhang J, Lindsey ML (2010) Extracellular matrix roles during cardiac repair. Life Sciences 87:391-400. doi:10.1016/j.lfs.2010.07.010

Kopatz I, Remy JS, Behr JP (2004) A model for non-viral gene delivery: through syndecan adhesion molecules and powered by actin. J Gene Med 6:769-776. doi:10.1002/jgm.558

Kopecek J, Kopeckova P, Minko T, Lu Z (2000) HPMA copolymer-anticancer drug conjugates: design, activity, and mechanism of action. Eur Pharm $\mathrm{J}$ Biopharm 50:61-81. doi:10.1016/S0939-6411(00)00075-8

Laçin N, Utkan GG, Kutsal T, Pişkin E (2011) Thermo-sensitive nipa-based copolymer and monosize polycationic nanoparticle for non-viral gene transfer to smooth muscle cells. J Biomater Sci 23(2012):577-592. doi:10.1163/092050611 $\mathrm{X} 555272$

Liang K, Liu F, Huang L (2004) Targeted gene delivery: the role of peptide nucleic acid in. Int $\mathbf{J}$ Peptide Res Ther 10:161-167. doi:0.1007/BF02484557

Libby P (2002) Inflammation in atherosclerosis. Nature 420:868-874. doi:10.1038/nature01323

Lv H, Zhang S, Wang B, Cui S, Yan J (2006) Toxicity of cationic lipids and cationic polymers in gene delivery. $\mathrm{J}$ Control Release 114:100-109. doi:10.1016/j.jconrel.2006.04.014

Mishra S, Webster P, Davis ME (2004) PEGylation significantly affects cellular uptake and intracellular trafficking of nonviral gene delivery particles. Eur J Cell Biol 83:97-111. doi:10.1078/0171-9335-00363

Mislick KA, Baldeschwieler JD (1996) Evidence for the role of proteoglycans in cation-mediated gene transfer. Proc Natl Acad Sci USA 93:12349-12354

Pişkin E (2005) Stimuli-responsive polymers in gene delivery. Exp Rev Med Devices 2:501-509. doi:10.1586/17434440.2.4.501

Pişkin E, Dinçer S, Türk M (2004) Gene delivery: intelligent but just at the beginning. J Biomater Sci 15:1181-1202. doi: $10.1163 / 1568562041753016$ 
Raffetto JD, Khalil RA (2008) Matrix metalloproteinases and their inhibitors in vascular remodeling and vascular disease. Biochem Pharmacol 75:346-359. doi:10.1016/j.bcp.2007.07.004

Ruponen M, Honkakoski P, Tammi M, Urtti A (2004) Cellsurface glycosaminoglycans inhibit cation-mediated gene transfer. J Gene Med 6:405-414. doi:10.1002/jgm.522

Siow RCM, Churchman AT (2007) Adventitial growth factor signalling and vascular remodelling: Potential of perivascular gene transfer from the outside-in. Cardiovasc Res 75(4):659-668. doi:10.1016/j.cardiores.2007.06.007

Thomas M, Klibanov AM (2003) Non-viral gene therapy: polycation-mediated DNA delivery. Appl Microbiol Biotechnol 62:27-34. doi:10.1007/s00253-003-1321-8

Tulis DA, Mnjoyan ZH, Schiesser RL, Shelat HS, Evans AJ, Zoldhelyi P, Fujis K (2003) Adenoviral gene transfer of fortilin attenuates neointima formation through suppression of vascular smooth muscle cell proliferation and migration. Circulation 107:98-105. doi:10.1161/01.CIR. 0000047675.86603.EB

Turk M, Dincer S, Yuluğ IG, Piskin E (2004) In vitro transfection of HeLa cells with temperature sensitive polycationic copolymers. J Control Release 96:325-340. doi: 10.1016/j.Jconrel.2004.01.013

Türk M, Dinçer S, Pişkin E (2007) Smart and cationic poly (NIPA)/PEI block copolymers as non-viral vectors: in vitro and in vivo transfection studies. J Tissue Eng Regen Med 1:377-388. doi:10.1002/term.47

Yan C, Boyd DD (2007) Regulation of matrix metalloproteinase gene expression. J Cell Physiol 211:19-26. doi:10.1002/jcp. 20948 